\title{
Cytotoxic and the proliferative effect of cuttlefish bone on MC3T3-E1 osteoblast cell line
}

\author{
La-ongthong Vajrabhaya ${ }^{1}$, Suwanna Korsuwannawong ${ }^{2}$, Rudee Surarit ${ }^{3}$
}

Correspondence: Suwanna Korsuwannawong

Email: suwanna.aut@mahidol.ac.th

\begin{abstract}
'Endodontic Section, Faculty of Dental Medicine, Rangsit University, Pathumtanee 12000, Thailand, ${ }^{2}$ Research Office, Faculty of Dentistry, Mahidol University, Bangkok 10400, Thailand,

${ }^{3}$ Department of Oral Biology, Faculty of Dentistry, Mahidol University, Bangkok 10400, Thailand
\end{abstract}

\section{ABSTRACT}

Objective: To evaluate the cytotoxic and the proliferative effect of cuttlefish bone on MC3T3-E1 osteoblast cell line. Materials and Methods: MC3T3-E1 cells were treated with 0.5, 1, 5, 25, 50, 100, or $200 \mu \mathrm{g} / \mathrm{ml}$ cuttlefish bone powder (CBP). Cytotoxicity was evaluated using the 3-(4,5-dimethylthiazol-2-yl)-2,5-diphenyltetrazolium bromide assay. This assay was also used to determine cell proliferation over 16 days of treatment with $0.5,25$, or $100 \mu \mathrm{g} / \mathrm{ml} \mathrm{CBP}$. Results: CBP was not cytotoxic to MC3T3-E1 cells at any concentration. The percentage of cell viability in the $0.5-200 \mu \mathrm{g} / \mathrm{ml} \mathrm{CBP} \mathrm{groups} \mathrm{dose} \mathrm{dependently} \mathrm{decreased}$ from $107.52 \pm 11.03$ to $92.48 \pm 5.60 \%$; however, the differences between the groups or the negative control group were not significant. At 16 days, $0.5,25$, and $100 \mu \mathrm{g} / \mathrm{ml}$ CBP groups showed $123.19 \pm 10.07 \%, 126.02 \pm 15.69 \%$, and $133.33 \pm 11.74 \%$ proliferation, respectively, that were significantly higher than that of the control group. Conclusion: These results indicate that CBP promotes osteoblast proliferation and may be a potential material to increase the number of osteoblasts in a bone defect in the oral cavity.

Key words: Cuttlefish bone powder, cytotoxicity, osteoblast cell culture, proliferation

\section{INTRODUCTION}

Cuttlefish bone $(\mathrm{CB})$ is a natural biomaterial source from the chamber of the cuttlefish that can be ground into a powder. $\mathrm{CB}$ is a brittle structure found in all members of the cephalopod family and is a chambered, gas-filled shell used to control floating. ${ }^{[1]}$ A gas and liquid mixture osmotically regulates the pressure inside the $\mathrm{CB} \cdot{ }^{[2,3]}$ The main chemical $\mathrm{CB}$ components are $87.3 \%-91.75 \%$ calcium carbonate and chitin. In addition, CB also contains trace amounts of silicon, aluminum, titanium, manganese, barium, and copper. ${ }^{[4]} \mathrm{CB}$ is a traditional Chinese medicine that is effectively used in treating gastritis and frequently used as a hemostatic agent after tooth extraction or rhinoplasty. ${ }^{[4]}$ Moreover, the synthesis

\begin{tabular}{|l|l|}
\hline \multicolumn{3}{|c|}{ Access this article online } \\
\hline Quick Response Code: \\
\hline
\end{tabular}

of Hydroxyapatite (HAp) from natural biomaterials, such as eggshell, ${ }^{[5]}$ coral $^{[6]}$ and $\mathrm{CB}^{[7]}$ has been reported.

Materials that enhance bone regeneration have a wide range of potential clinical applications, from treating nonunion fractures to spinal fusion. The use of porous material scaffolds with bioceramic and polymer components to support bone cell and tissue growth is a popular research topic. Current challenges include engineering materials that can match the mechanical and biological properties of the bone tissue matrix and support the vascularization of large tissue constructs. ${ }^{[8]}$ The most common biomaterials used for

This is an open access article distributed under the terms of the Creative Commons Attribution-NonCommercial-ShareAlike 3.0 License, which allows others to remix, tweak, and build upon the work non-commercially, as long as the author is credited and the new creations are licensed under the identical terms.

For reprints contact: reprints@medknow.com

How to cite this article: Vajrabhaya Lo, Korsuwannawong S, Surarit R.
Cytotoxic and the proliferative effect of cuttlefish bone on MC3T3-E1
osteoblast cell line. Eur J Dent 2017;11:503-7.
DOI: $10.4103 /$ ejd.ejd_159_17


bone tissue engineering include Hap, titanium, alumina, and polymers. ${ }^{[9]}$ Battistella et al. ${ }^{[10]}$ revealed that cell proliferation in a three-dimensional (3D) CB scaffold increased. They also suggested investigating the use of dynamic culture to improve cell proliferation and differentiation. The mechanical properties of natural bone are of interest in bone tissue engineering. A scaffold should have a highly porous matrix for transporting nutrients, oxygen, and metabolic products. ${ }^{[11]}$ In addition, cuttlefish bone powder (CBP) was added to paste or gel dentifrices or used directly with a toothbrush to clean the teeth and improve oral hygiene. ${ }^{[12,13]}$ We would like to investigate the biological properties of $\mathrm{CB}$ available in Thailand. In the present study, the biocompatibility and effect of CBP on MC3T3-E1 osteoblast cell proliferation were evaluated in vitro.

\section{MATERIALS AND METHODS}

\section{Cuttlefish bone powder preparation}

The bone inside the cuttlefish (from the Southern part of Thailand) was removed and cut in the middle into small pieces $(1 \mathrm{~cm} \times 1 \mathrm{~cm} \times 0.5 \mathrm{~cm})$ [Figure 1]. The CB was rinsed with deionized water, then boiled $10 \mathrm{~min}$ for getting rid of the odor and microorganisms. To desorb any impurities, the $\mathrm{CB}$ was dried at $103^{\circ} \mathrm{C}-105^{\circ} \mathrm{C}$ for $24 \mathrm{~h}$ and cooled in a desiccator at room temperature. The CB was crushed, pulverized,

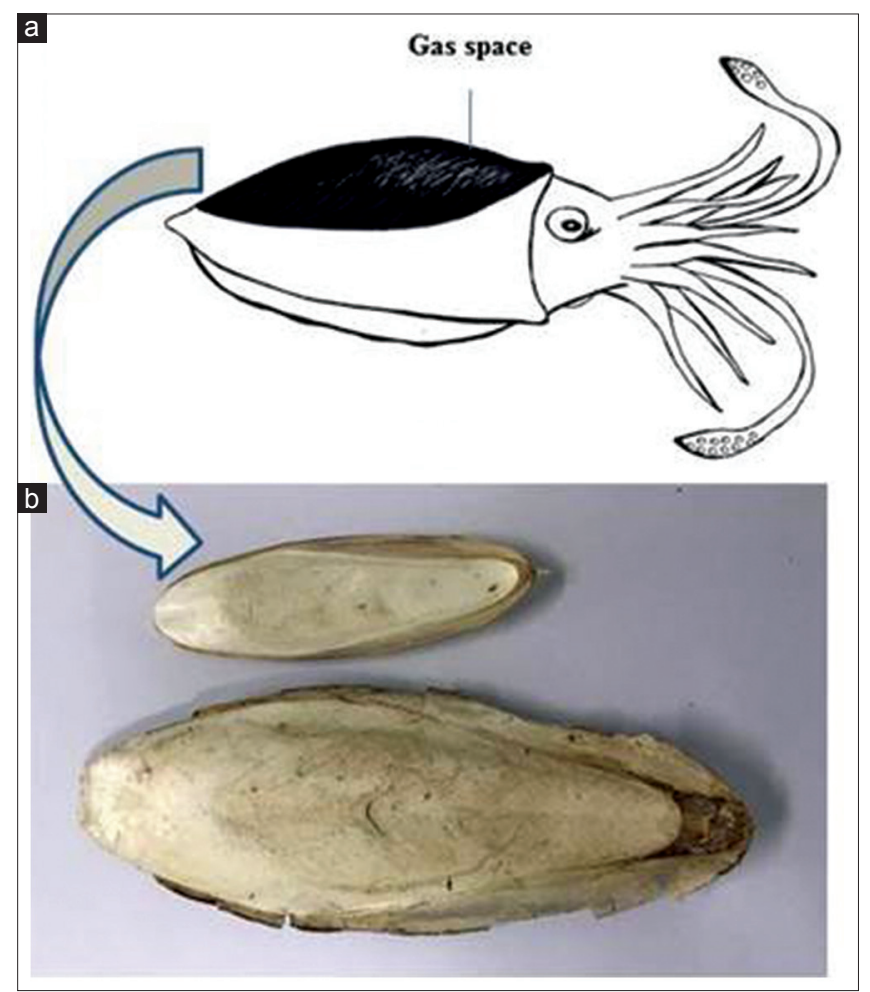

Figure 1: (a) Cuttlefish bone is the hard tissue in cuttlefish that functions in floatation. (b) Natural cuttlefish bone and sieved (Pass 80 mesh) into a 150-250 $\mu$ m particle powder. The $\mathrm{CB}$ powder (CBP) was used as the test material in the experiments.

\section{Test materials}

The CBP had a maximum $8 \%$ moisture and a $\mathrm{pH}$ range of 6.0-8.0. The minimum powder fineness passed through a No. 80 sieve with 75\% efficiency for sterilization before cell culture experiment. The CBP (200 mg) was mixed with $1 \mathrm{ml}$ of Dulbecco's modified Eagle's medium (DMEM, Invitrogen, CA, USA) for a $20 \%(\mathrm{w} / \mathrm{v})$ solution. The solution was incubated at $37^{\circ} \mathrm{C}$ in a $5 \% \mathrm{CO}_{2}$ atmosphere for $24 \mathrm{~h}$, per ISO 10993-12. ${ }^{[14]}$ The CBP stock solution was centrifuged at $3500 \mathrm{rpm}$ for $10 \mathrm{~min}$, and the supernatant was diluted into $0.5,1,5,25,50,100$, or $200 \mu \mathrm{g} / \mathrm{ml}$ solutions.

We used $3 \mathrm{~cm}^{2}$ polyurethane $/ 2 \mathrm{ml}$ of DMEM (Hatano Research Institute, Food and Drug Safety Center, Kanagawa, Japan) as a positive control per ISO 10993-5. ${ }^{[15]}$ The polyurethane films were sterilized by soaking in $70 \%$ alcohol for $1 \mathrm{~min}$, washed in normal saline for $1 \mathrm{~min}$, and left to dry. The dry films were immersed in DMEM and incubated at $37^{\circ} \mathrm{C}$ in a $5 \%$ $\mathrm{CO}_{2}$ atmosphere for $24 \mathrm{~h}$ before testing.

Thermanox ${ }^{\circledR}$ Coverslips (NUNCTM Naperville, IL, USA) $(6 \mathrm{~cm} 2 / 2 \mathrm{ml}$ of media) served as a negative control per ISO 10993-5. ${ }^{[15]}$ Thermanox ${ }^{\circledR}$ Coverslips were cut into small pieces, soaked in DMEM, and incubated in a $5 \% \mathrm{CO}_{2}$ atmosphere at $37^{\circ} \mathrm{C}$ for $24 \mathrm{~h}$ before testing.

\section{Cell culture procedure}

The cells used in this experiment were a continuous cell line, MC3T3-E1Subclone 4 Strain C57BL/ B mouse osteoblast-like cell line (ATCC ${ }^{\circledR}$ CRL-2593 ${ }^{\mathrm{TM}}$, USA). The cells were maintained in DMEM containing 10\% fetal calf serum, $200 \mu \mathrm{g} / \mathrm{ml}$ penicillin G, $200 \mu \mathrm{g} / \mathrm{ml}$ streptomycin, and $2 \mu \mathrm{g} / \mathrm{ml}$ fungizone at $37^{\circ} \mathrm{C}$ in a humidified $5 \% \mathrm{CO}_{2}$ atmosphere. The medium was changed every other day. When the cells reached confluence, they were detached using $0.2 \%(\mathrm{w} / \mathrm{v})$ trypsin and transferred to new culture flasks.

\section{Cytotoxicity evaluation}

At $80 \%$ confluency, the cells were trypsinized and plated in 96-well culture plates $\left(1 \times 10^{4}\right.$ cells/well). Each well contained $100 \mu \mathrm{l}$ of cell suspension, and the plates were incubated for $24 \mathrm{~h}$ at $37^{\circ} \mathrm{C}$ in a $5 \% \mathrm{CO}_{2}$ atmosphere. After $24 \mathrm{~h}$, the media was removed from each well. Subsequently, $100 \mu \mathrm{l}$ of eluent from the $0.5,1,5,25,50$, 100 , or $200 \mu \mathrm{g} / \mathrm{ml}$ CBP solutions or the positive/negative control was placed into the 96-well culture plates (8 wells/test material). After incubation for 24 hat $37^{\circ} \mathrm{C}$ in 
a $5 \% \mathrm{CO}_{2}$ atmosphere, cell viability was assessed using the 3-(4,5-dimethylthiazol-2-yl)-2,5-diphenyltetrazolium bromide (MTT) assay. The experiments were repeated in triplicate.

The mean optical density of the blank control group was set at $100 \%$ viability. The results for the experimental, positive control, and negative control groups were normalized to the blank control group. Statistical analysis was performed using the nonparametric Mann-Whitney test $(P<0.05)$. The relative cell count ratio was calculated from the following formula:

$\%$ Cell viability $=\frac{\text { O.D. }_{570 e}-\text { O.D. }}{\text { S70b }} \times 100$

Where O.D. ${ }_{570 \mathrm{e}}$ is the mean optical density of the $100 \%$ extracts of the test sample, O.D. ${ }_{570 \mathrm{c}}$ is the mean optical density of the control, and O.D. ${ }_{570 b}$ is the mean optical density of the blanks.

\section{Cell proliferation evaluation}

MC3T3 cells were cultured in $\alpha$-Minimum Eagle's Medium containing 10\% fetal bovine serum (FBS), $100 \mathrm{U} / \mathrm{ml}$ penicillin $\mathrm{G}$, and $100 \mu \mathrm{g} / \mathrm{ml}$ streptomycin at $37^{\circ} \mathrm{C}$ in a humidified $5 \% \mathrm{CO}_{2}$ atmosphere. The cells were treated with $0.25 \%$ trypsin for $5 \mathrm{~min}$ at $37^{\circ} \mathrm{C}$ and diluted with $\alpha$-MEM containing $10 \%$ FBS to a concentration of $1 \times 10^{5}$ cells $/ \mathrm{ml}$. The cells $\left(2 \times 10^{3}\right.$ cells/well $)$ were seeded in seven 96-well culture plates $(100 \mu \mathrm{l} /$ well $)$ and incubated at $37^{\circ} \mathrm{C}$ in a humidified $5 \% \mathrm{CO}_{2}$ atmosphere for $24 \mathrm{~h}$. The cells were treated with $0.5,25$, or $100 \mu \mathrm{g} / \mathrm{ml}$ of CBP solution and the media control group (10 wells/concentration/duration) for 1,3, 5, 7, 10,14, and 16 days. The MTT assay was used to determine cell proliferation at each concentration at each time point.

The percentage of cell proliferation of the three experimental groups was calculated using the mean optical density from 7 to 10 days this means the values from 7 to 10 days and was expressed as a percentage of the control values.

$\%$ cell proliferation $=$

$$
\begin{aligned}
& \text { rate of change }(\mathrm{OD}) \text { experiment } \\
& \frac{\text { group from day } 7 \text { to day } 10}{\text { rate of change }(\mathrm{OD}) \text { control }} \\
& \text { group from day } 7 \text { to day } 10
\end{aligned}
$$

\section{Statistical analysis}

Statistical analysis was performed using SPSS-18.0 software (SPSS Inc., IL, USA). The results are presented as the mean \pm standard deviation. Statistical analysis was performed using Student's $t$-test. A value of $P<0.05$ was considered to be statistically significant.

\section{RESULTS}

We determined the effect of CBP on MC3T3-E1 cell viability as percentage of cell viability [Figure 2]. CBP was not toxic to the MC3T3-E1 cells at any tested concentration. The percentage of cell viability in the $0.5-200 \mu \mathrm{g} / \mathrm{ml}$ CBP groups dose dependently decreased from $107.52 \% \pm 11.03 \%$ to $92.48 \% \pm 5.60 \%$, however, these differences were not significantly different from each other or the negative control group $(P>0.05)$, while the positive control group showed a significant 5-6-fold reduction compared with the other groups $(P<0.05)$. The results of the cell proliferation evaluation showed that cell proliferation in the CBP groups peaked at 14 days and decreased at 16 days [Figure 3], with the $0.5,25$, and $100 \mu \mathrm{g} / \mathrm{ml} \mathrm{CB}$ groups at 16 days demonstrating $123.19 \% \pm 10.07 \%$, $126.02 \% \pm 15.69 \%$, and $133.33 \% \pm 11.74 \%$ proliferation, respectively, which was significantly higher compared with the media control [Figure 4].

\section{DISCUSSION}

Tissue engineering in dentistry is a multidisciplinary field. The purpose of tissue engineering is to repair, maintain, or enhance tissue and organ regeneration. Promoting the organization of cells in a 3D architecture directs the growth and formation of the desired tissue. Bone has a low capacity for self-repair due to its limited vascular supply and low rate of chondrocyte mitosis. Currently, osteoconductive porous biodegradable materials are used in tissue engineering for bone

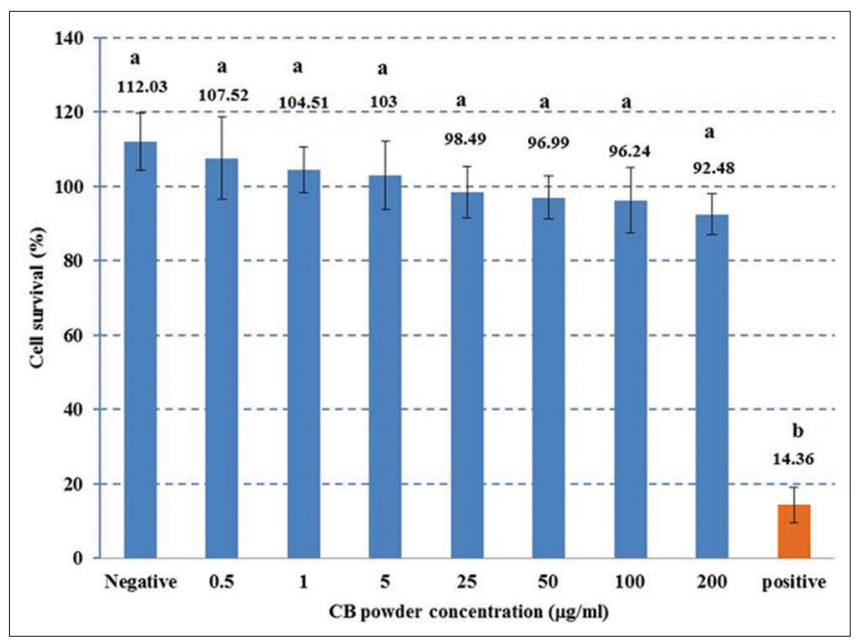

Figure 2: Cell viability percentages in the CBP, negative control, and positive control groups. Different superscript letters signify a significant difference between groups $(P<0.05)$ 


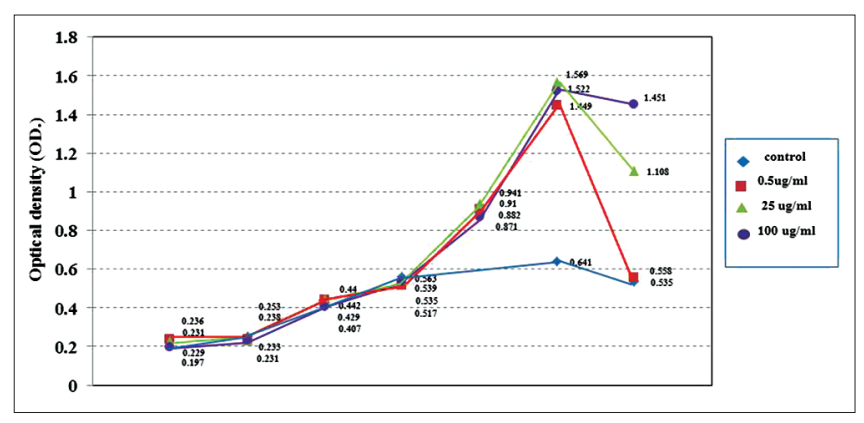

Figure 3: Cell proliferation as demonstrated by the 3-(4,5-dimethylthiazol-2-yl)-2,5-diphenyltetrazolium bromide optical density results from $1-16$ days

repair. Once the bone healing is accomplished, the newly formed tissue undergoes physiologic bone remodeling, which involves the coordinated action of osteoblasts and osteoclasts. ${ }^{[16]}$

Calcium phosphate-based materials can be used as a biomaterial for tissue engineering. Hap, $\mathrm{Ca}_{10}\left(\mathrm{PO}_{4}\right)_{6}(\mathrm{OH})_{2}$, is widely used as a bone substitute. ${ }^{[17]}$ The composition of Hap is the same as the mineral constituents in hard tissue, i.e., bone and teeth. Hap has several beneficial properties; it is nontoxic, osteoconductive, and biocompatible. Natural Hap biomaterials, such as coral and eggshell, have been recommended as the materials of choice in bone tissue engineering. ${ }^{[5]} \mathrm{CB}$ is a Hap material that has been used in dentistry for bone repair. There are two benefits of $\mathrm{CB}$ Hap in bone tissue engineering: the main component of $\mathrm{CB}$ is aragonite $\left(\mathrm{CaCO}_{3}\right)$ that has been converted into Hap and it also has a porous structure and bone-like architecture. ${ }^{[18]}$

Recently, Hap with a porous morphology has been used as a scaffold. The scaffold is placed in the bone defect area. This porous scaffold is beneficial for bone defect repair due to its effectiveness in cell attachment, differentiation, and proliferation, generating bone healing. ${ }^{[19]}$ Polycaprolactone is a polymer commonly added to a Hap scaffold to increase its mechanical properties. ${ }^{[20]}$

CB has been proposed as a suitable material for a bone tissue scaffold. We selected MC3T3-E1 as the target cells in our experiment because they are cell line and have the capacity to differentiate into osteoblasts. MC3T3-E1 has been established from a C57BL/ 6 mouse calvaria and selected on the basis of high alkaline phosphatase activity in the resting state. Our study revealed the same biocompatibility with MC3T3-E1 osteoblast cell line as shown in other studies. ${ }^{[10,18]}$ None of the CBP concentrations

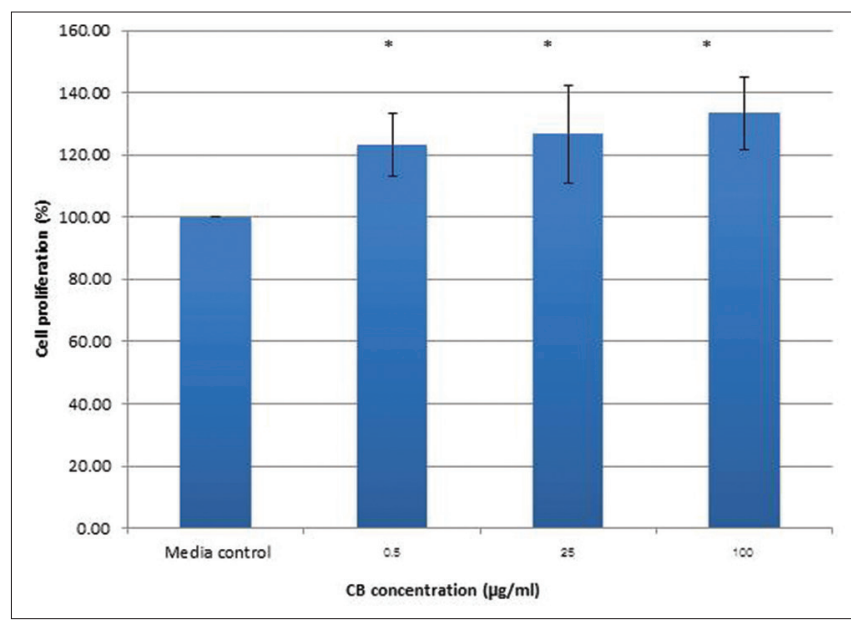

Figure 4: Percentage of cell proliferation in the $0.5,25$, and $100 \mu \mathrm{g} / \mathrm{ml}$ cuttlefish bone groups at 16 days. *Indicates a significant difference between the control group $(P<0.05)$

we evaluated were cytotoxic to the MC3T3-E1 cell line. The percentage of cell viability was rather high and similar to that of the negative control, while that of the positive control group was significantly fold lower.

We evaluated cell proliferation using three levels of CBP concentration; low $(0.5 \mu \mathrm{g} / \mathrm{ml})$, middle $(25 \mu \mathrm{g} /$ $\mathrm{ml})$, and high $(100 \mu \mathrm{g} / \mathrm{ml})$ along with media controls. We found that the exponential phase of cells treated under these conditions was between 7 and 10 days. The percentage of cell proliferation was calculated from the optical density in the exponential phase of the $C B$ and control groups. The low-, medium-, and high-CB groups demonstrated percent cell proliferation of $123.17 \%, 124.02 \%$, and $133.33 \%$, respectively, and were significantly higher from the media control group at 16 days. Our results correspond with those of Kim et al., ${ }^{[21]}$ where PCL/CB-Hap scaffold implantation generated significantly higher new bone formation. Yildirim et al. ${ }^{[22]}$ found that the mineral composition of $\mathrm{CB}$ was compatible with human bone tissue and suggested its use as a scaffold. In addition, Kannan et al. ${ }^{[23]}$ estimated that a CB channel size of $100 \times 200 \mu \mathrm{m}$ would be beneficial for bone ingrowth. Moreover, CB and shrimp shell-derived chitosan displayed good biocompatibility and supported cell attachment and growth. ${ }^{[2]}$

A study reported that raw $\mathrm{CB}$ contains $0.05 \mathrm{ppm}$ mercury, $0.52 \mathrm{ppm}$ copper, $2.42 \mathrm{ppm}$ zinc, $0.39 \mathrm{ppm}$ lead, and $0.07 \mathrm{ppm}$ cadmium and is not cytotoxic in vitro. ${ }^{[25]}$ Zreiqat et al. ${ }^{[26]}$ suggested that implant surfaces coated with $\mathrm{Mg}^{2+}$ promote optimal osteogenesis and lead to the maintenance of nature and healthy bone. 
The $\mathrm{Mg}^{2+}$ ion has an important role in integrins binding to their respective ligands. Integrins transduce signals from the extracellular environment to the interior of the cell or vice versa for cellular migration, adhesion,

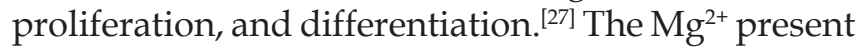
in $\mathrm{CB}$ is a likely reason for the cell proliferation observed in our study.

\section{CONCLUSION}

The current study revealed that $0.5-200 \mu \mathrm{g} / \mathrm{ml} \mathrm{CBP}$ were biocompatible with the MC3T3-E1 cell line and that $0.5-100 \mu \mathrm{g} / \mathrm{ml} \mathrm{CBP}$ induced a high percentage of cell proliferation compared with control. These findings suggest that $\mathrm{CB}$ has the potential to improve in vivo bone defect healing by increasing cell proliferation.

\section{Financial support and sponsorship}

Nil.

\section{Conflicts of interest}

There are no conflicts of interest.

\section{REFERENCES}

1. Rexfort A, Mutter J. Stable isotope records from Sepia officinalis - A key to understanding the ecology of belemnites? Earth Planet Sci Lett 2006;247:212.

2. Gower D, Vincent JF. The mechanical design of the cuttlebone and its bathymetric implications. Biomimetics 1996;4:37-57.

3. Vogel S. Living in a physical world VIII. Gravity and life in water. J Biosci 2006;31:309-22.

4. "Cuttlefish Bone". Chinese Herbs Healing. Available from: http:// www.chineseherbshealing.com/cuttlefish-bone-cuttlebone/. [Last retrieved on 2016 Apr 29].

5. Park JW, Bae SR, Suh JY, Lee DH, Kim SH, Kim H, et al. Evaluation of bone healing with eggshell-derived bone graft substitutes in rat calvaria: A pilot study. J Biomed Mater Res A 2008;87:203-14.

6. Tran CT, Gargiulo C, Thao HD, Tuan HM, Filgueira L, Michael Strong D. Culture and differentiation of osteoblasts on coral scaffold from human bone marrow mesenchymal stem cells. Cell Tissue Bank 2011;12:247-61.

7. Ivankovic H, Gallego Ferrer G, Tkalcec E, Orlic S, Ivankovic M. Preparation of highly porous hydroxyapatite from cuttlefish bone. J Mater Sci Mater Med 2009;20:1039-46.

8. Molly MS. Biomaterials for bone tissue engineering. Mater Today 2008;11:18-25.

9. Bucholz RW, Heckman JD, Court-Brown CM, Tornetta P, Koval KJ,
Wirth MA, In: Early JS, editor. Rockwood and Green's Fractures in Adults. ${ }^{\text {th }}$ ed. Philadelphia: Lippincott Williams and Wilkins; 2006.

10. Battistella E, Mele S, Foltran I, Lesci IG, Roveri N, Sabatino P, et al. Cuttlefish bone scaffold for tissue engineering: A novel hydrothermal transformation, chemical-physical, and biological characterization. J Appl Biomater Funct Mater 2012;10:99-106.

11. Milovac D, Gallego Ferrer G, Ivankovic M, Ivankovic H. PCL-coated hydroxyapatite scaffold derived from cuttlefish bone: Morphology, mechanical properties and bioactivity. Mater Sci Eng C Mater Biol Appl 2014;34:437-45.

12. American Dental Association. "Toothpaste". 2010. Available from: https://en.wikipedia.org/wiki/Toothpaste\#cite_ref-ADAtoothpaste_1-1. [Retrieved from 2017 Jan 15].

13. Vajrabhaya LO, Korsuwannawong S, Harnirattisai C, Teinchai C. Changes in the permeability and morphology of dentine surfaces after brushing with a Thai herbal toothpaste: A preliminary study. Eur J Dent 2016;10:239-44.

14. International Standard Organization. ISO 10993-12 Biological Evaluation of Medical Devices - Part 12: Sample Preparation and Reference Materials. Geneva: ISO; 2012.

15. International Standard Organization. ISO 10993-5 Biological Evaluation of Medical Devices - Part 5: Tests for In vitro Cytotoxicity. Geneva: ISO; 2009.

16. Korpi JT, Aström P, Lehtonen N, Tjäderhane L, Kallio-Pulkkinen S, Siponen $\mathrm{M}$, et al. Healing of extraction sockets in collagenase-2 (matrix metalloproteinase-8)-deficient mice. Eur J Oral Sci 2009;117:248-54.

17. Pilliar RM, Filiaggi MJ, Wells JD, Grynpas MD, Kandel RA. Porous calcium polyphosphate scaffolds for bone substitute applications-in vitro characterization. Biomaterials 2001;22:963-72.

18. Ivankovic $\mathrm{H}$, Tkalcec E, Orlic S, Ferrer GG, Schauperl Z. Hydroxyapatite formation from cuttlefish bones: Kinetics. J Mater Sci Mater Med 2010;21:2711-22.

19. Shin H, Jo S, Mikos AG. Biomimetic materials for tissue engineering. Biomaterials 2003;24:4353-64.

20. Causa F, Netti PA, Ambrosio L, Ciapetti G, Baldini N, Pagani S, et al. Poly-epsilon-caprolactone/hydroxyapatite composites for bone regeneration: In vitro characterization and human osteoblast response. J Biomed Mater Res A 2006;76:151-62.

21. Kim BS, Yang SS, Lee J. A polycaprolactone/cuttlefish bone-derived hydroxyapatite composite porous scaffold for bone tissue engineering. J Biomed Mater Res B Appl Biomater 2014;102:943-51.

22. Yildirim OS, Okumus Z, Kizilkaya M, Ozdemir Y, Durak R, Okur A Comparative quantative analysis of sodium, magnesium, potassium and calcium in healthy cuttlefish backbone and non-pathological human elbow bone. Can J Anal Sci Spectrosc 2007;52:270-5.

23. Kannan S, Rocha JH, Agathopoulos S, Ferreira JM. Fluorine-substituted hydroxyapatite scaffolds hydrothermally grown from aragonitic cuttlefish bones. Acta Biomater 2007;3:243-9.

24. Prasitsilp M, Jenwithisuk R, Kongsuwan K, Damrongchai N, Watts P. Cellular responses to chitosan in vitro: The importance of deacetylation. J Mater Sci Mater Med 2000;11:773-8.

25. Cho ML, Heu MS, Kim JS. Food component characteristics of cuttle bone as a mineral source. J Korean Fish Soc 2001;34:478-82.

26. Zreiqat H, Howlett CR, Zannettino A, Evans P, Schulze-Tanzil G, Knabe $\mathrm{C}$, et al. Mechanisms of magnesium-stimulated adhesion of osteoblastic cells to commonly used orthopaedic implants. J Biomed Mater Res 2002;62:175-84.

27. Hynes RO. Integrins: Versatility, modulation, and signaling in cell adhesion. Cell 1992;69:11-25. 